Cracked Coverage 



\section{Cracked Coverage}

\section{TELEVISION NEWS,}

THE ANTI-COCAINE CRUSADE, AND

마

THE REAGAN LEGACY

JIMMIE L. REEVES AND

$\square$

RICHARD CAMPBELL

Duke University Press, Durham and London 1994 


\section{(C) 1994 Duke University Press}

All rights reserved Printed in the United States of America on acid-free paper $\infty$

Designed by Cherie Holma Westmoreland

Typeset in Sabon with Frutiger display by Tseng Information Systems, Inc.

Third printing, 1998

Library of Congress Cataloging-in-Publication Data

Reeves, Jimmie Lynn.

Cracked coverage: television news, the anti-cocaine crusade, and the Reagan legacy / Jimmie L. Reeves and Richard Campbell.

p. $\mathrm{cm}$.

Includes bibliographical references and index.

ISBN 0-8223-I449-5 (alk. paper). -ISBN 0-8223-I49I-6 (pbk.: alk. paper)

I. Television broadcasting of news-United States. 2. Narcotics, Control of--United States. 3. Cocaine industry-United States. I. Campbell, Richard, 1949- - II. Title. PN4888.T4R44 1994

$070.1 ' 95$-dc20 93-4I4II CIP 
To Gay D. Reeves and Dianna Campbell, Our Partners in Life, For Keeping the Faith 
